\title{
Perception, Presence, and Sacramentality in a Postmodern Context
}

by

\author{
Judith M. Kubicki ${ }^{*}$
}

Christian theology is, by its very nature, contextual. This characteristic requires ongoing dialogue with each place where faith is alive and active so that the received tradition might flourish in communities of diverse time, place, and culture. This article offers a contribution to that dialogue by exploring how sacramentality is perceived in our postmodern context. Several frameworks derived from phenomenology will be applied to an analysis of the eucharist as ritual activity in order to discover how the unfolding of Christ's presence in the gathered assembly can be expressed and perceived.

The bishops of the Second Vatican Council eloquently expressed the contextual nature of theology in article four of the 1965 Pastoral Constitution on the Church in the Modem World (Gaudium et Spes):" "in every age, the church carries the responsibility of reading the signs of the times and of interpreting them in the light of the Gospel, if it is to carry out its task. In language intelligible to every generation, it should be able to answer the ever recurring questions which people ask about the meaning of this present life and of the life to come, and how one is related to the other. We must be aware of and understand the aspirations, the yearnings, and the often dramatic features of the world in which we live." The work of the Second Vatican Council was a monumental effort to put theology in dialogue with culture. However, even as the documents were being promulgated, the world from which and to which it was speaking was already evolving from what is usually termed a "modern" perspective to one that today is generally designated "postmodern."2 The theological investigations, the biblical research, and the pastoral reflections that constituted the work of the council were the fruits of a modern world. The challenge of the present time-a brief forty years later-is

* Dr Judith M. Kubicki, CSSF (Kubicki@fordham.edu), is an assistant professor of theology at Fordham University in Bronx, New York, USA.

1 All quotations from Vatican II documents are taken from Austin Flannery, ed., Vutican Council II: Constitutions, Decrees, Declarations; A Completely Revised Translation in Inclusive Language, Northport, NY: Costello 1996.

2 The meaning of these terms will be discussed later in the article. 
to bring the theology and pastoral insights of Vatican 11 into dialogue with the postmodern context.

\section{Liturgical Renewal}

As a result of Vatican II's Constitution on the Sacred Liturgy (Sacrosanctum Concilium, 1963), the worship life of the church has been both reinvigorated with new life and energy and beset with controversy and disappointment. The great majority of Roman Catholics are at home worshiping in the vernacular and have welcomed the reformed rites. Others ne what they see as the loss of a sense of awe and mystery in the liturgy. New directives in recent documents published by Rome and the United States Conference of Catholic Bishops regarding particular aspects of celebrating mass and devotion to the eucharist outside mass have re-ignited public debate on the role of the laity in the liturgy aud placement of the reserved eucharistic species. Some view these developments as attempts to reverse the reforms initiated by the council. Others regard them as a response to grass roots appeals to rescue Roman Catholic worship from laxity or wrongheaded or irreverent innovation. Perhaps a key to interpreting the current tensions and gaining insights for promoting authentic worship today begins with taking another look at the guiding principles of the liturgical reform within the context of postmodernity. This paper offers a small contribution to that effort by considering the perception of Christ's presence in the gathered assembly in light of the challenges posed by postmodernity. Article seven of the Constitution on the Sacred Liturgy states:

To accomplish so great a work Christ is always present in his church, especially in liturgical celebrations. He is present in the sacrifice of the Mass both in the person of his minister, "the same now offering, through the ministry of priests, who formerly offered himself on the cross," and most of all in the eucharistic species. By his power he is present in the sacraments so that when anybody baptizes it is really Christ himself who baptizes. He is present in his word since it is he himself who speaks when the holy scriptures are read in church. Lastly, he is present when the church prays and sings, for he has promised "where two or three are gathered together in my name there am I in the midst of them" (Matt 18:20).

Within the celebration of the eucharist, four modes of Christ's presence are identified: in the word (sacred scripture), the presider (priest as leader of prayer), the gathered assembly, and the bread and wine. A fifth mode refers to other sacramental celebrations. Since Vatican II, there has been an increased awareness and appreciation for the presence of Christ in the word and, to a lesser extent, the presider. The scholarly work on the presence of Christ in the eucharistic elements (bread and wine) continues to be significant and extensive. Developing a theology that promotes an understanding of Christ's presence in the assembly gathered for worship is receiving increased attention. However, much more work is required to provide a theological framework for understanding this belief and articulating it effectively.

In an effort to understand how an assembly gathered for eucharist is able to perceive the presence of Christ in its midst, this paper will address three questions. First, what are the characteristics of postmodernism that might directly impact this religious belief and experience? Second, what role does sacramentality play in the contemporary Roman Catholic imagination? Third, how can "presence" be understood and "perceived" in a postmodern world?

\section{The Characteristics of Postmodernity}

Scholars generally agree that the label "postmodern" originated in the 1930 s to designate certain developments in the arts. Its usage gained more widespread attention when it was applied to certain forms of architecture in the $1970 \mathrm{~s}^{3}$ Postmodernism rejects the modern mindset that views the human person as an autonomous rational subject. This attitude that originated with the Enlightenment culminated in the twentieth century view that human existence could be brought under rational management through technology. ${ }^{4}$ Modernity believed that knowledge is certain, objective, and good. As a result, reality in many of its varied aspects was put under the regular scrutiny of reason. In addition to elevating the importance of reason, modernity likewise elevated the importance of the freedom of the individual, understood to be an autonomous self existing outside the constraints of any tradition or community. ${ }^{5}$

Postmodernism rejects the modern mindset. It is no longer convinced that knowledge is inherently good. It likewise rejects the notion of the dispassionate autonomous knower and belief in the inevitability of progress. The events of September 11, 2001 have affirmed these postmodern convictions in undeniable ways. Mounting threats of terrorism, despite the escalation of strategies for war and homeland defense, highlight the fragility of security, peace, and freedom. The rational management of the planet appears to be a colossal failure. Even spending

3 Stanley J. Grenz, A Primer on Postmodernism (Grand Rapids, Ml: Eerdmans 1996) 2.
+ Ibid., 3.

5 Ibid., 4. 
billions of dollars has failed to bring order and certainty to a time of chaos and unspeakable human suffering. On the positive side, the failure of the intellect to serve as sole determiner of belief has resulted in the re-emergence of appreciation for the emotions and intnition as valid avenues for arriving at truth. Integration is favored over analysis and the universe is viewed, not as mechanistic and dualistic, but as historical, relational, and personal. Reality is characterized as relative, indeterminate, and participatory. ${ }^{6}$

Deconstructionists operating from within a postmodern perspective propose that meaning occurs when the interpreter enters into dialogue with a given text. However, since each interpreter reads reality differently, the possibility of a universal worldview diminishes. In other words, all is difference. ${ }^{7}$ Pluralism becomes the hallmark of postmodern culture; contradictory styles are juxtaposed as in a collage. ${ }^{8}$ Even so, the postmodern perspective is sensitive to the social dimension of reality and keenly conscious of the significance of the local community for providing interpretations of reality. It is, in fact, within the framework of particular communities that postmodernism allows for the possibility of truth claims. But since meaning can occur only when the interpreter enters into dialogue with a given text, interpretation replaces knowledge.

Another characteristic of postmodernism is the frequent blurring of reality and fiction, presence and absence. Technology, particularly in the form of the screenmovie, television or computer-has contributed to this phenomenon. In the first place, the television screen provides a collage of images that juxtapose the irreconcilable, e.g., atrocities of war reported in news bites interrupted by commercials for luxury automobiles. Secondly, technology eliminates spatial and temporal distinctions, merges past and present, the distant and the local. This blurring of boundaries is only heightened by the experience of surfing the web on the personal computer. The traditional contrast between the subjective self and the objective world disappears as the screen becomes an extension of us and we an extension of it. ${ }^{9}$ The latest form of technology to incorporate the screen is the cell phone. In ways similar to the television and computer, the cell phone serves to overcome spatial and temporal distinctions and merge the distant with the local. However, even without the screen, the cell phone disrupts the ordinary experience of personal presence and absence. Persons can be available twenty-four/seven to those who are absent. Conversations with those who are abseut intrude in public spaces.

6 See ibid.. 2-14.

${ }^{7}$ See ibid., 106, and Martin Heidegger, Poetry, Language, Thought (New York: Harper \& Row 1971) 202-10.

${ }^{3}$ Grenz, A Primer on Postmodemism, 6-20.

See ibid., 34-35.
Finally, the postmodern age can be identified as the period that has witnessed the demise of the meta-narrative. Criticized for displaying absolute, universal, and cognitive pretensions, master narratives have been abandoned and exchanged for the radical particularity and contextuality of individual or local narratives 10 It is no longer possible to appeal to a central legitimating myth. In fact, not only have all reigning master narratives lost their credibility, but even the idea of a grand narrative is no longer considered tenable. This contemporary awareness of the hegemonic assumptions of the master narrative seems to expose the arrogance of the Western perspective. It might actually be more accurate to say that the postmodern age has witnessed, not the demise of the meta-narrative, but the demise of the belief that there was or is one universal grand narative.

What are the implications of these developments for the Christian narrative? The fundamental plurality of the postmodern situation highlights the particular and contingent nature of all discourses and narratives, including "founding" naratives. Does this lack of universal perspective signal the end of narratives that negotiate both individual and collective identity? Lieven Boeve, in his work on sacramental presence in a postmodern context, argues that it does not. Rather, he suggests that it requires an acknowledgment that plausibility now must mean contextual plausibility. "This need not mean the demise of the Christian narrative as such. A shift in context may imply a loss of plausibility, but as Boeve observes, it also "represents a challenge to renew the effort of recontextualisation, to look for a new relation between the received tradition and the changed context." 12

Acknowledging that the context has changed requires a reexamination of old assumptions. If the contemporary context exhibits postmodern characteristics that reject the superiority of reason, the possibility of a universal worldview, and the intelligibility and legitimacy of master narratives, we need to reflect on how this perspective might open up new avenues for exploring the intuitive and the relational dimensions of the sacramental imagination. Further, if postmodern tech nology has helped to create the blurring of distinctions between reality and fiction, presence and absence, the subjective self and the objective world, we need to reflect on how such lack of boundaries specifically influences our understanding of the local and participatory dimensions of Christian faith and rituals.

${ }^{10}$ Lieven Boeve, "Thinking Sacramental Presence in a Postmodern Context: A Playground for Theological Renewal" in Sacramental Presence in a Postmodem Context, ed. L. Boeve and L. Leijssen (Leuven, Belgium: Leuven University Press 2001) 15.

11 Ibid., 16.

12 Ibid., 17. 
Since the integration favored in the postmoden approach promotes a worldview that is relational, personal, and participatory, worship may once again be recognized as an important locus for religious insight and the expression of religious belief. The type of knowing that occurs within worship can be described as neither rational nor scientific. Rather, because it is symbolic activity, it is primarily non-discursive and exhibitive. That is, meaning is not asserted by means of propositional content in worship, but exhibited in the interplay of symbolic activity. ${ }^{13}$ lt is this fundamental belief that the activity of God can be experienced in this way that provides the foundation for the notion of sacramentality.

\section{The Notion of Sacramentality}

Kevin lrwin asserts that the notion of sacramentality must be retrieved if liturgy and sacraments are to survive in the contemporary world. Sacramentality is a particular way of seeing the world and looking at life that provides the framework for the way we live in the world and with each other. This framework enables us to view the world as the locus where God reveals God-self to us and where we respond to that revelation. A sacramental imagination takes seriously those everyday experiences the church appropriates to celebrate its life in God through the liturgy. ${ }^{14}$ Built on such a worldview, liturgy and sacraments mediate the action of the divine in the human. The sacred is manifested in the secular; God is perceived as present and active within the world.

The notion of sacramentality, however, is not limited to an experience of God's presence. No matter how much the sacred becomes present through the mediation of symbolic activity, no revelation of God can ever be complete or total. So there is, alongside the experience of God's presence, the experience of God's absence. This revelation of God's hiddenness is also a dimension of sacramentality. By emphasizing how God is discoverable in the here and now, sacramentality also invites us to yearn for the fullness of God's presence in eternity. ${ }^{15}$

Kenan Osbome also views the sacramentality of the universe as key to understanding the church's sacraments in a postmodern context. ${ }^{16}$ However, since God's action is always a "unique blessing/action that occurs at a unique time and in a

Is Judith M. Kubicki, Liturgical Music as Ritual Symbol: A Case Sndy of Jacques Berthier's Taizé Music (Leuven, Belgium: Peeters 1999) 115.

${ }^{14}$ Kevin Irwin, "A Sacramental Worid-Sacramentality as the Primary Language of Saeraments," Worship 76 (2002) 197-99.

15 Ibid., 203

:6 See Kenan B. Osborne, Christian Sacraments in a Postmodem World: A Theology for the Third Millennium (New York: Paulist Press 1999) 50-53 unique space for unique people," he points out that there can be no "essential" general sacramentality. ln other words, both God's action and the human response are "profoundly temporal, profoundly spatial, and profoundly relative." 17 Osbone's descriptions of sacramentality are consonant with the postmodern perspective because they focus on the importance of the here-and-now and the local. However, this does not mean that we can think of God as occupying a localized position or site. Even when God communicates to human beings in a sacramental event, God is experienced as hidden and ungraspable. ${ }^{18}$ It is only in the particularity of time, place, and persons that the event of God's self-communication can be experienced.

In reflecting on the postmoden challenge to belief in the sacramentality of existence, Lieven Boeve identifies two requirements of the Christian narrative. The first is that it open itself up to the transcendent in a contemplative way so that the transcendent as "interruptive event" can enter. The second is that it bear witness to the transcendent, not in a hegemonic way, but by means of its own, always fragmentary rituals, symbols, words, and stories. In this way, belief in the sacramentality of existence is not used to legitimate the Christian narrative or offer redemption to an unredeemed world. Rather, it opens up that very unredeemedness that undermines the possibility of depending on human constructions. ${ }^{19}$ Boeve explains:

The sacramentality of life, clarified and celebrated in the sacraments, is no longer considered as participation in a divine being, nor anticipation of a selffulfilling development, but as being involved in the tension arising from the irruption of the divine Other into our human narratives, to which the Christian narrative testifies from of old. Sacramental living and acting thus presuppose the cultivation of a contemplative openness, and testify in word and deed to that which reveals itself in this openness as a trace of God.20

A posture of contemplative openness is thus identified as a key criterion for perceiving the sacramentality of life. Such openness to transcendence apprehends all of life's dimensions as dynamically interrelated. ${ }^{21}$

Godfried Cardinal Danneels also addresses the challenges of maintaining a posture of contemplative openness in this postmodern age. To highlight the fundamental quality of liturgical activity, Danneels refers to participants as "homo liturgicus." The fundamental attitude is one of receptivity, readiness to listen,

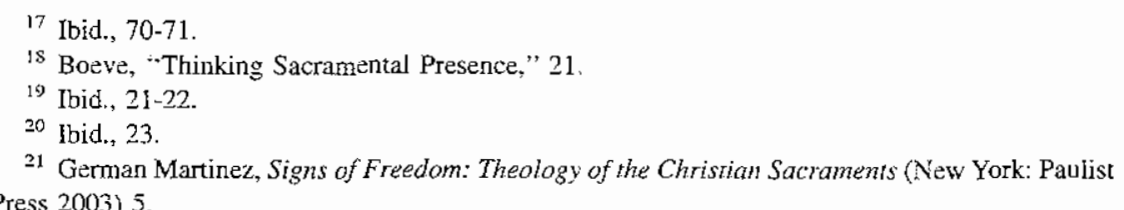

Ibid, 21-22

21 German Martinez, Signs of Freedom: Theology of the Christian Sacraments (New York: Paulist Press 2003) 5. 
self-giving and self-relativizing. ${ }^{22}$ Danneels describes this fundamental attitude as an "orientation towards God, readiness to listen, obedience, grateful reception, wonder, adoration, and praise. It is an attitude of listening and seeing, of what Guardini called 'contemplating', an attitude so alien to the 'homo faber' (worker) in many of us." This openness or receptivity is intimately dependent on the experience of the senses, especially, as Danneels points out, listening and seeing. Thus the body - both individually and collectively-becomes the location for the experience of the presence of God

The sacramental theologian Louis-Marie Chauvet highlights the importance of bodiliness when he explains that "the human being does not have a body, but is body." 23 This "I-body," Chauvet argues, exists only as woven, inhabited, and spoken by the triple body of culcure, tradition, and nature. The human being as corporeal is the place where the triple body - social, ancestral, and cosmic - is symbolically joined. ${ }^{24}$ Furthermore, the liturgy is for Chauvet "the powerful pedagogy where we learn to consent to the presence of the absence of God, who obliges us to give him a body in the world." 25

Thus the notion of sacramentality involves an appreciation of the significance of creation, particularly of bodiliness, in communicating God's presence in the world. It is an event of disclosure that is both interpersonal and revelatory. Furthermore, it is an event in the concrete, not the abstract. It always involves a particular or unique moment, place, and person or group of persons. The possibility or manner of being receptive or open to a unique event of disclosure is, nevertheless, affected by the postmodern context in which the event is experienced. In other words, our perception, our receptivity, our openness to God's presence in the bodiliness of the world is influenced by a mindset that has lost confidence in the rational and prefers, once again, non-rational ways of knowing.

Today the sacramental imagination faces the challenge of a pluralistic environment that denies the possibility of a shared story, even as technology claims to provide universal access to potentially limitless information. Yet, the blurring of spatial and temporal distinctions may actually promote an openness to experiences of both presence and absence that require reconfigurations of the imagination, specifically the sacramental imagination. It is this imaginative capacity to

22 Godfried Cardinal Danneels, "Liturgy Forty Years After the Second Vatican Council: High Point or Recession" in Liturgy in a Postmodern World, ed. Keith Pecklers (New York: Continuum 2003) 10.

${ }^{23}$ Louis-Marie Chauvet, Symbol ond Sacrament: A Sacramental Reinterpretation of Christian Existence (Collegeville, MN: The Liturgical Press 1995) 149.

24 Ibid., 149-50.

25 Ibid., 265. perceive the "interruption" of the divine within human life that is operative in the church's sacramental celebrations of God's activity in the world.

From this general understanding of postmodernism and of sacramentality we can proceed to the final section of this paper which will consider two points: (1) frameworks that phenomenology offers for understanding "presence" and "perception," and (2) how these phenomenological frameworks can be used to understand further how the gathered assembly perceives the presence of Christ in its midst.

\section{Engaging the Insights of Phenomenology}

Although phenomenology is often considered a modern rather than postmodern philosophy, its potential for providing resources for addressing the third question raised here is significant. How might "presence" be understood and "perceived" in a postmodern world? It was the phenomenologist Edmund Husserl who first took seriously the role of absence in human experience. Because of his work, presence can no longer be discussed without taking into account the corresponding experience of absence. In fact, phenomenology offers several useful frameworks experience of absence. In fact, phenomenolog sacramental event: (1) the signifor exploring percepton significance of the body; (3) identity in manifolds; ficance of horizon; (2) the significance of the body, (3) identity in will be sum(4) absence and presence; and (5) disclosurc marized and considered in relation to the question of perceiving the presence of Christ in the gathered assembly.

One of the key affirmations of phenomenology is that every object of perception is given in a horizon of other objects and/or meanings that contribute to its significance. Husserl argues that an individual object can only be perceived within a field of other objects. ${ }^{26}$ In other words, context is critical for the act of perception. Maurice Merleau-Ponty takes a similar approach. He deals with the basic structures of living-in-the-world that take into account perception, as well as the body, space, time, and other persons. He explains that "perception is not a science of the world, it is not even an act, a deliberate taking up of a position; it is the background from which all acts stand out, and is presupposed by them. The world is not an object such that I have in my possession the law of its making; it is the natural setting of, and field for, all my thoughts and all my explicit perceptions." 27

26 See Edmund Husserl, Corresian Meditations: An Introduction to Phenomenology (The Hague: (1960) Martinus Nijhoff 1960), especially, the second, fourth, and fith meditatons, soe alsoid , Zur Phanomenologie der Intersubjektivität, Zweiter Teil: 1921-1928 (The Hague: Martimus Nijhoff 1973) 115, and nologie der Intersubjektivität, Zweiter Teil. Dritter Teil 1929-1935 (The Hague: Martinus Nijhoff 1973) 604.

${ }_{27}$ Maurice Merleau-Ponty, Phenomenology of Perception (London: Routledge \& Kegan Paul 1962, 1986) $\mathrm{x}$. 
For Merleau-Ponty, perception is the context within which human beings gain access to truth. ${ }^{28}$

Since perception involves the senses, existential phenomenology highlights the significance of the body as the source of the intentionalities that structure our experience of daily life in the world (das Lebenswelt). ${ }^{29}$ Phenomenologists use the word "intentionality" rather differently from the ordinary use of the word "intention." For them, intentionality refers to the conscious relationship we have to an object. ${ }^{30}$ Perception necessarily involves not only attending to a particular object, but also attending to accompanying objects and actions, as well as to their perceived meanings. This has important ramifications for analyzing ritual and doing litnrgical theology. Contemporary approaches to litnrgical theology begin with the ritual event in order to discover theological meaning. In the case of an awareness of the presence of Christ, that presence is perceived through the network of symbolic actions that constitute the sacramental event. This symbolic network of images, music, color, space, silence, scent, architecture, and text is the langnage that both shapes and expresses onr experience of the world. As language, it becomes the point of convergence for interpersonal relationships. Our perception of Christ's presence in the gathered assembly is thus constructed from within sacramental rituals.

The third element of phenomenology is "identity in manifolds." Robert Sokolowski uses the example of the cnbe to explain the concept. A cube can be shown from different perspectives and yet presented through all of them. That is, the identity of the cube can be expressed in a "manifold" of ways. This structure operates in the perception of anything that can be presented to us. ${ }^{31}$ Two additional ideas are important. The first is that there is a distinction between an object's identity and its manifold appearances. The second is that the identity is not simply the sum of its appearances, but rather transcends them all. Finally, while identities in manifolds can be related to a single perceiver or knower, a mnch richer array of manifolds comes into play when the presence of other persons is introduced. The inter-subjectivity achieved within a gronp provides the potential for deeper objectivity and a richer transcendence when multiple manifolds are shared. ${ }^{32}$ This dimension emerges in a particularly important way in communal rituals.

${ }^{28}$ Ibid., xvi.

29 F. J Crosson, "Phenomenology" in The New Carholic Encyclopedia, 2nd ed, (Washington, DC: Gale and The Catholic University of America Press 2003) 11:233.

${ }^{30}$ See Robert Sokolowski, Introduction to Phenomenology (Cambridge: Cambridge University Ptess 2000) 8 .

${ }^{31}$ Ibid., 27.

32 Ibid., 30-32.
Theologians have used phenomenological language to speak of the presence of Christ in the eucharist. Michael Witczak refers to article seven of the Constitution on the Sacred Liturgy as an articulation of the "manitold" presence of Christ in the liturgy. ${ }^{33}$ Peter Fink's analysis of the four modes of Christ's presence in the eucharist also reflects a phenomenological perspective. The starting point for discussing an encounter with the Christ who is present, Fink points out, is not any one particular mode (food, word, minister, assembly), but the total eucharistic action as an expression of the Christ who is present. ${ }^{3+}$ Yet a phenomenological perspective would cantion against equating the identity of Christ's presence, given through the manifold expressions of his presence, as simply the sum total of all the modes. Rather, the experience of Christ's presence transcends each mode individually and together. The phenomenological notion of identity in manifold provides an important framework for understanding the experience of perceiving the presence of Christ in the eucharist under the four modes and for plumbing its various levels of theological meaning.

The notion of presence and absence is another formal structure that is useful for our consideration. Phenomenology distinguishes between filled intentions (those that target something that is present) and empty intentions (those that target something that is absent). ${ }^{35}$ lts approach to the experience of absence as an aspect of memory is particularly useful for a discussion of eucharist, since memorial is integral to its nature. Since both filled and empty intending are directed toward the same object, there is an identity "behind" and "in" presence and absence. That is, presence and absence are "of" one and the same object or person. ${ }^{36}$

In reflecting on the interplay between presence and absence, phenomenology focuses on absence to a degree that makes its approach unique. Things may be absent because they are future, far away, forgotten, concealed, or beyond comprehension. ${ }^{37}$ From the point of view of phenomenology, the identity of an object or person is given across the difference of presence and absence, not exclusively in presence. Whether an object or person is absent or present, we always intend it in its identity. That identity is the same regardless of whether it is present or absent. ${ }^{38}$

Phenomenology's treatment of presence and absence is helpfnl in analyzing the relationship of perception to remembering and anticipation in the liturgical context. The object that is presented to us throngh perception is always given in a

3s See Michael G. Witczak, "The Manifold Presence of Christ in the Liturgy," Theological Studies 59 (1998) 680-702.

34 Peter E. Fink, "Perceiving the Presence of Christ," Worship 58 (1984) 221.

3.5 Sokolowski, Introduction to Phenomenology, 33.

36 Ibid., 35-36.

37 lbid., 37.

${ }^{36}$ Ibid., 39. 
mixture of presences and absences. When an object is remembered, it is perceived as absent. In this case, remembering is a particular manifold by which the object is presented to our perception. ${ }^{39}$ When an object is anticipated, we also experience it as absent, but because we can imagine it as present, we can live in the future. ${ }^{40}$ This ability to intend toward what is absent is particularly critical in dealing with the eschatological nature of the eucharist and Christ's promise to "come again." There is a constant tug in the life of faith between experiencing the presence and absence of God. This dialectic is particularly evident in the eucharist, where the church proclaims its belief in Christ's presence even as it anticipates the final consummation of all things in Christ. ${ }^{41}$

Finally, the phenomenological understanding of disclosure and evidencing can provide fnrther insights into our consideration of the presence of Christ in the liturgical assembly. In his writings, Sokolowski repeatedly describes hnman beings as "datives ${ }^{42}$ of manifestation." In one place he defines the "I" as "the entity to whom the world and all the things in it can be given, the one who can receive the world in knowledge." ln another he asserts the importance of allowing "a thing to manifest itself to us." 43 When we operate from within the phenomenological attitude, we begin to look at things as they are manifested or disclosed to us; that is, we begin to look at things in their truth and in their evidencing. At the same time, we experience the seIf as the dative to whom beings are disclosed. ${ }^{+4}$ What is the nature of the truth of disclosure? It is the simple "presencing" to us of an intelligible object, the manifestation of what is real or actual. Something is presented to us or a state of affairs simply unfolds. ${ }^{45}$

In phenomenology, the word "evidence" functions more as a verb-evidencingthan as a noun. Evidencing means to bring about the truth or bring forth a presence. It is both performance and articulation of a state of affairs. It is a veritable event in the life of human beings. This "eventing" achieves not only the perfection of the subject who gets the point or sees what is going on. It also achieves a perfection in the object that is manifested and known. The word "evidence" or "evidencing" is appropriate to the phenomenological euterprise and significant to the study of the sacramental event because it aptly expresses that we are active when things present themselves. That is, we do something when intelligible objects present

39 Ibid., 66-68.

${ }^{40}$ Ibid., 71-74.

${ }^{+1}$ See Judith M. Kubicki, “. . Christ Will Come Again.” The Living Light 40:2 (2003) 44-50.

${ }^{+2}$ When Sokolowski uses the term "dacive," he is observing its grammatical meauing. The dative

is a grammatical case of a word that is either the indirect object of a verb or the object of a preposition.

+3 Sokolowski, Introduction to Phenomenology, 44, 93 .

4 tbid.. 64-65.

${ }^{45}$ Ibid. 158-59. themselves to us; we are not merely passive recipients. In other words, while we are datives of disclosure, we are also nominatives of manifestation. Such a claim captures the state of affairs when the assembly gathers for worship. The assembly both evidences the presence of Christ and receives that disclosure in an ongoing process, one that is not accomplished once and for all, but that continues and reinforces itself beyond the initial moment. The presence of Christ that is brought to light, however, emerges out of absence and vagueness. ${ }^{46}$

\section{Conclusion}

Mnch can be learned from taking a contextual approach to theology today. In the first place, an examination of cultural and philosophical developments within the postmodern context discloses several potentially favorable conditions for enabling meaningful experiences of the sacramental rites. A heightened respect and interest in non-rational ways of knowing and a worldview that is historical, relational, and personal provides fertile gronnd for a renewed appreciation for all types of symbolic activity. At the same time, the effects of technology on our experience of spatial and temporal boundaries challenge our understanding of presence and absence, as well as perception. Rather than denying or ignoring a culture that rejects the notion of a meta-narrative, Christians need to dialogne with the culture in order to discover new ways of expressing the received tradition in a changed cultural context.

Fostering a sacramental imagination or sacramental worldview in our worship assemblies is essential to a deepening appreciation of the presence of Christ, not only in worship, but also in our contemporary world. This sacramental imagination is broader and deeper than simple faith in the efficacy of the sacramental rites and it is particularly snited to the postmodern perspective with its penchant for the here-and-now and the local. Belief in the sacramentality of existence is nurtnred by a posture of contemplative openness or receptivity to transcendence that is glimpsed in human experience that is inherently bodily.

Lastly, phenomenology provides useful frameworks for contemplating the human experience of perception and presence. In its articulation of the importance of context, particularly the body, this philosophical approach can assist in identifying how we experience absence and presence, disclosure and evidence. Phenomenol ogy provides a way of understanding human persons as both datives and nominatives, ${ }^{47}$ as objects and subjects, as receivers and actors, of manifestation. A deeper understanding of the dynamic involved in evidencing as a way of bringing forth

${ }^{46}$ Ibid., 160-65.

17 The nominative case is the subject of the verb. When the verb is active voice, the subject is the doer of the acrion. 
presence can provide new ways to express and experience the unfolding of Christ's presence in the assembly gathered for formal worship and in the liturgy of daily life in the world.

When an assembly gathers for worship, one of its tasks is to bring to a kind of presence that which is experienced as absent-the resurrected Christ. This does not happen automatically. Phenomenology helps us understand that this requires work, the work of the people as a community (leitourgia) and of each individual in the assembly. Things disclose themselves to us, but human beings are the agents. And in the liturgy, human beings are agents of God. This, after all, is what active participation is all about. So what is it that enables or inspires the gathered assembly to take up this communal task? Why do so many opt instead for a privatized piety even in a communal setting? The issue is larger than what happens within a liturgical rite. It includes the relationship between politics and epistemology. When baptized members of the church are made to feel like abject subjects who are not allowed to raise questions or offer alternate viewpoints, they cannot see themselves as either moral agents or agents of truth. Certainly they cannot see themseives as datives of manifestation, as persons having the power of disclosure. The result is a retreat into subjectivism, the cancellation of public truth in favor of private relativism. ${ }^{48}$

Ironically, efforts to protect public truth with a strong arm may result in more widespread privatization of religious belief and a weakened appreciation of the gathered assembly as the locus of the resurrected Christ. The euphoric excitement of the early post-Vatican II years encouraged the assembly to imagine their place in the church in new ways. Their sense of being vital, responsible members of the church resulted in increased involvement in all aspects that were open to them, but particularly in the liturgy. The current ecclesial climate discourages that kind of enthusiasm, commitment, and self-understanding. The gathered assembly's awareness of itself as the locus of the presence of the resurrected Christ is critical to their appreciation of the fullness of the eucharistic mystery, their self-understanding as baptized Christians, and their active participation in the liturgy of the church. Attention to the cultural context may provide insights into the dynamics that promote or diminish that awareness.

${ }^{48}$ Ibid., 205-6. Sokolowski discusses this issue in terms of the sovereign state. I have applied his insights. mutatis mutandis, to the current situation in the Roman Carholic Church. 